\title{
Suullisen ja kirjallisen runouden kerrostumia
}

\author{
Kallio, Kati, Tuomas M. S. Lehtonen, Senni Timonen, Irma-Riitta Järvinen \& \\ Ilkka Leskelä 2017: Laulut ja kirjoitukset. Suullinen ja kirjallinen kulttuuri uuden \\ ajan alun Suomessa.
}

Helsinki: SKS. 624 sivua.

\section{Kaarina Koski}

/ aulut ja kirjoitukset on vaatimattomaan ulkokuoreen piiloutunut suurteos. Se tarkastelee uuden ajan alun eli 1500- ja 1600-lukujen suomenkielistä runokulttuuria kokonaisuutena, johon kuuluvat sekä kansanrunot että oppineiden runot ja erityisesti niiden väliset vuorovaikutussuhteet. Käsittelyssä ovat muun muassa pyhimyksiin liittyvät kansanomaiset runot, rukoukset ja loitsut, uuden ajan alun virsirunous ja sen suhteet kansanrunouteen, oppineiden laatimat kirjalliset runot, kansanomaiset pilkkalaulut ja sananlaskut, Piispa Henrikin surmavirsi taustoineen sekä Kaarle-herttuan runo poliittisine vaikuttimineen. Runojen lisäksi esitellään ajankuvia sekä oppineiden näkemyksiä oman aikansa runoudesta. Monitieteinen kokonaisuus hyödyntää eniten historian ja kirkkohistorian, kielen- ja kirjallisuudentutkimuksen sekä folkloristiikan aloista runouden ja kansanuskon tutkimuksen näkökulmia. Se kiinnittyy kansanihmisten kirjallistumista koskeviin ajankohtaisiin tutkimusintresseihin ja samalla hyödyntää uusimpia näkökulmia runokulttuureihin varioivina, toisiltaan lainaavina ja monikerroksisina.

Viiden tutkijan saumattomana yhteistyönä toteutuneen tutkimuksen erityisiä ansioita ovat alkuperäislähteiden huolellinen tulkinta aikalaiskontekstissa ja samalla vanhoihin tutkimusparadigmoihin kiinnittyneiden ennakkoasenteiden hylkääminen. Näin on pystytty sekä oikaisemaan folkloristiikassa kauan vaalittuja virhetulkintoja että löytämään kokonaan uusia näkökulmia, joita oppineita ja rahvasta erikseen tarkastelevat tutkimukset eivät voisi tavoittaa. Teos tarjoaa lukijalle suuria valaistumisen hetkiä. Perusteellisuudesta huolimatta teksti on helppolukuista, ja näkökulmat ja tulokset esitellään selkeästi. Paikoin ilmaisu on niin osuvaa ja kaunista, että lukiessa hymyilyttää. Sellainen on esimerkiksi kuvaus suullista laulukulttuuria käyttävistä yhteisöistä heterogeenisina puheyhteisöinä ja niissä tunnettujen lajien monikäyttöisyydestä (s. 40-44). 


\section{Etnopoeettinen ote myös oppineiden runoihin}

Laulut ja kirjoitukset hyödyntää etnopoetiikan keskeistä ideaa ja tarkastelee runoja, niiden arvoa ja merkityksiä runokulttuurin omien käyttötapojen ja esteettisten normien pohjalta. Yleensä etnopoeettisen analyysin kohteena ovat suulliset kulttuurit, mutta tässä se osoittaa voimansa oppineiden kulttuurin tulkinnassa. 1500-luvun oppineiden runoutta on tavattu arvostella 1800- ja 1900-lukujen kirjallisten runousihanteiden pohjalta huonoksi ja kömpelöksi, ja reformaatioajan kirkonmiehiä on moitittu kalevalamitan vihaamisesta ja kansanuskon hävittämisestä. Mutta jos otamme tosissamme uuden ajan alun oppineet, heidän kirjoittamansa kuvaukset ja heidän edustamansa kulttuurin, kuva sekä oppineiden runoista että rahvaankulttuurista muuttuu. (S. 407.)

Esitän tästä kaksi esimerkkiä, joista ensimmäinen on Mikael Agricola ja hänen syynsä listata Daavidin psalttarin esipuheeseen hämäläisiä ja karjalaisia epäjumalia. Kansanuskon tutkimuksessa on ollut tapana tarkastella luetteloa kontekstistaan irrotettuna ja tulkita sitä tekstin ja tutkijan omien intressien pohjalta. Tutkijasukupolvi toisensa jälkeen on hellinyt ajatusta reformaattorin humanistisesta kiinnostuksesta kansanuskoa kohtaan. Mutta tässä teoksessa on kaivettu esille se aikalaiskeskustelu, jonka osana tätäkin julkaisua tulee tulkita. Siihen ja esipuheen proosamuotoiseen osuuteen perehtyminen osoittaa, että syy oli teologinen. Ensimmäinen käsky "Ele cumardha weraita Jumaloita" oli Agricolan koko teoksen johtoajatus. Uuden opin oli määriteltävä uudelleen myös siihen sopimaton toiminta. Olennaista oli liittää katoliset tavat osaksi menneisyyteen kuuluvien pakanatapojen listaa. (S. 85-88, 93-95.) Agricola oli reformaattori, ei folkloristi.

Toinen on sen asian selvittäminen, oliko varhaisten virsirunoilijoiden tavoitteena hävittää kalevalamittainen runous pakanallisena ja paheksuttavana. Ensimmäisen suomenkielisen virsikirjan julkaisijan Jacobus Finnon perustelut virsilaulun paremmuudesta sisältävät varsin ikäviä arvioita maallisista lauluista. Ylimääräisiä oletuksia tekemätön luenta kuitenkin osoittaa, että paheksunta kattaa vain laulujen maalliset sisällöt. Tämän teoksen painokkaimmin toistettu argumentti on, että virsirunouden siirtäminen saksalaisen esikuvan mukaisena Suomeen ei ollut hyökkäys kalevalaista runokulttuuria kohtaan. Virsilaulu oli kokonaan uusi genre, ja sommitellessaan Saksassa kuulemiaan virsiä suomen kielelle Finno halusi erottaa ne sekä katolisista liturgisista lauluista että maallisista lauluista. Luultavasti siksi hän pysytteli tiiviisti saksalaisten esikuvien mukaisessa riimillisessä, jambisessa mitassa, joka myös sopi virsisävelmiin paremmin kuin trokee. Samaan aikaan oppineet käyttivät kalevalamittaa omissa runoissaan sekä sananlaskuissa, joten se oli täysin hyväksytty ilmaisun tapa. Kansanrunoista tutut tyylipiirteet kuten alkusointu alkoivat 1600 -luvulle tultaessa lisääntyä myös virsissä. (S. 108-123, 406-410.)

Kontekstualisointi tekee oikeutta kaikelle 1500-luvulla kirjatulle runoudelle. Ajan runokulttuurin laajempi tarkastelu viittaa siihen, että tavujen poisjäänti - joka on myös varsinaissuomalainen murrepiirre - ja mitan joustavuus olivat ajalle tyypillistä poetiikkaa. Myös Saksassa ja Ruotsissa runomitan säännöt tiukentuivat vasta 1600-luvulla. Länsisuomalainen trokeinenkaan runo ei ollut säännöllisen 8-tavuista. Tuon ajan länsimaisen runousopin mukaan osa murrelmasäkeistä voitiin tulkita puhtaan jambisiksi, ja samaan verbi- tai sijamuotoon päättyvät paralleelisäkeet riimillisiksi. Tätä taustaa vasten runotyyppien yhdistely oli norminmukaista, ja samoin olivat ne oppineiden runot, joita on arvioitu huonoiksi myöhempien ihanteiden pohjalta. (S. 395-397, 406-409.) 
Samalla tavoin kuin tutkimuskohteena olevia runoja ja uuden ajan alun oppineita, omassa kulttuurisessa kontekstissaan tarkastellaan myös niitä 1800-luvulla ja 1900-luvulla toimineita tutkijoita, joiden tulkintoja ohjasivat oman aikansa intressit. Uusia tulkintoja rakennetaan osin jo aiemmin esitetyn oppihistoriallisen kritiikin päälle. Tämä tehdään kunnioittavasti, sillä aikansa ihanteisiin perustuvista virhearvioista huolimatta aiempien tutkijapolvien työ on nimenomaan mahdollistanut sen, mitä tehdään nyt.

\section{Pyhimykset pienen ja suuren tradition välissä}

Kansanuskon tutkijana pidän pyhimyksiä koskevia osuuksia teoksen parhaana herkkuna. Laulut ja kirjoitukset sisältää tiiviin yleisesityksen pyhimyksiin liittyvistä traditioista, minkä jälkeen käsitellään erikseen suomalaisen runokulttuurin tärkeimmät pyhimykset Anna, Tapani eli Stefanus, Katariina ja neitsyt Maria. Jokaisen heistä kohdalla korostuvat myös erityyppiset teoreettiset kysymykset.

Pyhän Annan eli neitsyt Marian äidin kohdalla pääsemme seuraamaan pyhimyksen ekologista sopeutumista elinkeinoja ja vaurautta varjelevaksi haltijahahmoksi muiden haltijoiden rinnalle. Idässä korostuu suhde metsään metsän emäntä Annikkina, jolta pyydettiin suojaa myös metsässä laiduntavalle karjalle. Lännessä taas painottuu kotitalouden emännyys avaimineen sekä parannustoimi, jossa Anna esiintyy usein yhteistyössä neitsyt Marian kanssa.

Stefanuksella on kaksoiselämä marttyyrina, joka todistaa Kristuksen syntymästä, sekä tapaninpäivän kulkueisiin liittyvänä tallirenkinä, miesten perinteeseen kuuluvan hevoskultin keskeishahmona. Suomalaisissa tapaninlauluissa on tallentunut muutos miehen ja hevosen kosmista yhteyttä kuvaavista trokeisista riittirunoista joulun inmettä todistaviksi kiertuelauluiksi ja lopulta 1800-luvulla luterilaista sävyä saaneeksi riimilliseksi arkkipainatteeksi, jossa kansanomaistuneeseen Tapanin hahmoon yhdistetään jälleen marttyyri Stefanus. Viimeksi mainittua kuvaillaan näin:

Tuntemattoman tekijän kirjoittama arkkivirsi viljeli erilaisia riimillisiä, loppusoinnullisia mittoja ja rytmejä, jotka sulautuivat vanhempiin tapoihin ja lauluihin ja joiden voittokulussa on kuin laboratoriossa nähtävissä, miten kirjallinen ilmaisu lomittuu moninkertaisesti suullisen kanssa. (S. 183.)

Tapaninlaulujen kehityksen selvittäminen on ollut monitieteinen tehtävä ja hyödyntänyt maallisia ja kirkollisia viranomaisasiakirjoja, kansatieteellisiä kuvauksia sekä kansanrunoutta. Merkillepantavaa on se, että viimeistä vaihetta edustaneita arkkipainatteita ei aikanaan ole luokiteltu kansanrunoudeksi eikä otettu SKVR:aan, koska ne olivat painettuja, jambistuneita ja luterilaisuuteen viittaavia. Niillä oli kuitenkin suullisia esikuvia, ja tapaninpäivän kiertuelaulajat käyttivät niitä sittemmin apuna laulujen opettelussa.

Pyhä Katariina Aleksandrialainen on elänyt rahvaan traditiossa kahdessa toisistaan erillisessä kontekstissa: marttyyrikuolemaa käsittelevässä Katriinan poltto -runossa sekä karjanhoitoriiteissä. Katriinan poltto yhdistää todennäköisesti keskiajalla sepitettyä kalevalamittaista legendarunostoa kirjalliseen Katariinan legendaan sekä esikristillisiä teemoja sisältävän myyttirunoston säeaineksiin. Kansankulttuurissa ei ilmeisesti katsota sen olevan yhteydessä karjanhoitoon ja erityisesti lampaisiin liittyvään Katriina kipo kaposeen, jolle osoitettujen rituaalitekstien laajat merkityskentät punovat yhteen yliluonnollisen, naiseuden ja eläinten suhdetta (s. 205). 
Neitsyt Marian kohdalla aineisto laajenee ja kuva monimuotoistuu, koska Marian merkitys läpäisee koko kristillisen kansankulttuurin. Maria pysyi reformaation jälkeenkin merkittävänä kirkollisena hahmona, vaikka hänet muutettiin jumalallisesta olennosta esikuvalliseksi ihmiseksi. Kansankulttuurissa hän on esikuvallinen parantaja ja auttaja kristillisessä alkuajassa, mutta hänen apuunsa ja ruumiilliseen läsnäoloonsa turvaudutaan myös parannushetken preesensissä. Mariaan liittyy suuri määrä eri asiayhteyksissä kertautuvia ominaisuuksia ja avuja. Jo vanhimmista käräjälähteistä löytyvät parannusloitsussa Jesuxen verj punainen, Marian makja maito palovammojen parannukseen, ja maidon tärkeä rooli ulottuu kirkkotaiteesta aina raudan syntyyn (s. 225, 274-277). Toinen on Marian suojeleva vaippa, jonka mielikuvissa yhdistyy laaja kirjo vaikutteita aina kirkkotaiteesta esikristillisiin hahmoihin (s. 305-308).

Pyhimysten kohdalla tulee esiin perinteen kerroksellisuus ja erilaisten traditioiden välinen vuorovaikutus. Suomalainen pyhimyksiin liittyvä perinne ei ole syntynyt suoraan kirkollisista esikuvista, vaan taustalla on myös muunkielistä kansanperinnettä kuten runoja, rukouksia ja kertomuksia, joita kielitaitoiset tai kaksikieliset henkilöt - mahdollisesti myös papit - ovat suomentaneet. Esimerkiksi Marian kohdalla myös ortodoksinen ja katolinen kuvasto ovat sulautuneet toisiinsa ja kansanomaisiin mielikuviin monikerroksisessa vuorovaikutuksessa. Tärkeää onkin huomata, etteivät 1800-luvulla tallennetut pyhimyksiin liittyvät runot ja loitsut olleet jäänteitä aiemmilta ajoilta vaan käyttäjilleen nykyhetkessä toimivia ja mielekkäitä rituaaleja.

\section{Kaikella on syynsä}

Laulut ja kirjoitukset selvittää ansiokkaasti erilaisten runomittojen kehitystä ja niiden suhdetta toisiinsa aikana, jolloin rahvaan ja oppineiden runokulttuurit eivät olleet toisistaan erillisiä. Teos seuraa riimillisen laulun leviämistä kansankulttuuriin virsilaulusta ja oppineiden runoista käsin, koska niistä on olemassa kirjallisia lähteitä. Kuitenkin todetaan mahdolliseksi, että kansanomaiset riimilliset laulut ovat voineet kehittyä keskiajalla myös skandinaavisten ja germaanisten kontaktien tuloksena. Kaikkien kiinnostavien kysymysten ratkaisemiseen ei yksinkertaisesti ole lähdeaineistoa.

Kalevalamitan monikäyttöisyys sekä rahvaan että oppineiden kulttuurissa tulee selväksi; samoin se, etteivät uuden ajan alun virsirunoilijat turmelleet sitä. Kalevalamitan aktiivisen kansanomaisen käytön arvellaan väistyneen Turun seudulta 1700-luvun kuluessa. Yhtenä mahdollisena tekijänä voidaan pitää herätysliikkeitä, joiden myötä rahvas ryhtyi omaehtoiseen virsilauluun ja virsien sepittämiseen. Erilaiset runomitat, käyttötavat ja rytmit elivät kauan rinnakkain. Sisämaassa kalevalamittainen runokulttuuri jatkui pitempään. Ritvalan helkakulkueet, joissa laulettiin Mataleenan, Inkerin ja Annikaisen virsiä, menettivät paikallisen merkityksensä Sääksmäellä 1830-luvun ja 1890-luvun välisenä aikana. Syiksi on mainittu paitsi kansanvalistus, myös liikenneyhteydet ja väestön lisääntynyt liikkuvuus, joiden myötä neitojen tapa laulaa kulkueena joutui etenkin muualta tulleiden pilkan kohteeksi. (S. 399-401, 419.)

Laulut ja kirjoitukset on runsaudensarvi, joka toisaalta esittelee runomittojen kehitystä ja ajankuvaa, toisaalta selvittää tarkoin tekstien välisiä yhteyksiä, syitä ja seurauksia. Miksi Kaarle-herttuan sotaretkestä Suomeen sepitettiin yksityiskohtainen runo? Miksi piispa Henrikin surmavirrestä laadittiin vielä luterilaisella ajalla, 1600-1700-luvun vaihteessa, koristeellisia 
käsikirjoituksia? Kuka Annikainen oikein oli? Koko kirja on varsin laaja luettavaksi kerralla. Lukuja voi kuitenkin nauttia myös yksi kerrallaan ja vaikkapa lukea vain itselleen läheisimmät aihepiirit. Vaikka vasta kokonaisuus antaa täyden kuvan käsillä olevan ilmiön monimuotoisuudesta, luvut toimivat hyvin myös erikseen.

Laulut ja kirjoitukset on merkittävä paneutuvan, monitieteisen yhteistyön voimannäyte. Se kokoaa yhteen uskomattoman laajan asiantuntemuksen eri aloilta ja todistaa, että vanhat lähteet kannatti lukea uudestaan vielä kerran.

Folkloristiikan dosentti Kaarina Koski on erikoistunut kerronnan ja kansanuskon tutkimiseen ja toimii tällä hetkellä tietokirjailijana. 